\title{
Development of Perinatal Medicine in Different Geographic Areas
}

José M Carrera

\begin{abstract}
An overview is given of the evolution of perinatal medicine from its origin to its current state. Emphasis is placed on the birth of this new discipline in Europe and the USA, as well as on the contributions made to it by different countries. The main protagonists of subsequent changes are highlighted, as are the advances made in perinatal technology. To do so, the evolution and difficulties in introducing modern perinatal medicine are discussed. To conclude, current maternal, perinatal and infant mortality rates are compared with past figures.
\end{abstract}

Keywords: Perinatal medicine, History of perinatal medicine, Perinatologist in the world, Evolution of perinatal medicine.

How to cite this article: Carrera J M. Development of P erinatal Medicine in Different Geographic Areas. Donald School J Ultrasound Obstet Gynecol 2013;7(2):113-127.

\section{Source of support $\mathrm{Nil}$}

Conflict of interest: None declared

\section{INTRODUCTION}

The quality of perinatal care as well as maternal and perinatal mortality rates, vary considerably depending on the geographic area being studied. This is fundamentally due to the socioeconomic situation of each country, but also due to cultural and political circumstances. These variables explain why perinatal medicine has developed differently in the planet's various regions. ${ }^{9}$

\section{WESTERN EUROPE}

There is no doubt that perinatal medicine saw its beginnings in Europe, followed al most at the same time by the U nited States. In Europe, its development was particularly strong in those countries with a high technological capacity such as Germany, France, Great B ritain and Italy. 1,2,5,10

The 'European A ssociation of Perinatal M edicine' was founded in Berlin in 1968, one year after the creation of the 'German Society of Perinatal Medicine' and the 'International A cademy of Perinatal M edicine' was founded in B arcelona 2005. ${ }^{4}$

Until 50 years ago, the capacity for studying the fetus was minimal. It was basically limited to the auscultation of the fetal heart beat using a stethoscope, the pal pation of the abdomen to assess the approximate growth of the fetus and what the mother said about the fetal movements that she could feel.

Perinatal medicine took its first steps when the first amniocentesis was performed for the purpose of determining the diagnosis of Rh erythroblastosis (1952). This opened up a wide range of diagnostic possibilities in Europe, including fetal karyotyping and biochemical testing. Fuchs and Riis (1956) were the first to determine the sex of a fetus through the study of chromatin in the amniotic fluid obtained by means of puncture. Subsequently, Erich Saling invented the amnioscopy (1962), thanks to which it was possible to study the color, aspect and quantity of amniotic fluid without entering the amniotic sac. ${ }^{15}$

Thanks to the first tests carried out on the amniotic fluid between 1960 and 1965, two groups in Europe-the first in Liverpool (Finn and Clarke) and the second in Freiburg (Schneider and Preissler)-demonstrated that a prophylaxis for $\mathrm{Rh}$ erythroblastosis was possible, as a result of which this technique was introduced in 1966.

The first cardiotocography (CTG) prototype was developed in Düsseldorf by $\mathrm{K}$ onrad $\mathrm{H}$ ammacher between 1960 and 1966. This gave rise to what later became known as biophysical fetal monitoring during labor. The use of CTGs in hospitals was introduced in 1969. Today's CTG helps midwives and obstetricians to monitor pregnancies and births all over the world.

A t almost the same time (1961), Erich Saling developed the fetal blood analysis (FBA) technique, which was introduced into hospitals before CTG. The main role of the $\mathrm{FBA}$ is to confirm or exclude presumed hypoxia when the CTG is suspicious or pathological. Kubli correlated CTG traces with pH values during labor (1969). The combined use of the two techniques has resulted in a dramatic reduction in perinatal mortality.

The world's pioneers in ultrasound diagnostics were Ian Donald and K ratochwil, who between 1950 and 1960, with the help of a number of engineers, devel oped a device able to see images of the fetus, the placenta and the pelvic organs. ${ }^{16} \mathrm{~A}$ major quantitative advance was made when moving images (real time) took over from fixed images (static mode). From 1970, a second generation of European sonographers emerged, among whom $M$ anfred Hansmann stands out, using commercial machines manufactured in Germany to expand the diagnostic horizons of ultrasound. These machines, such as the V idoson, were fundamentally different from the cumbersome static scanners used in the UK, Scandinavia and A merica. M anfred Hansmann, together with Hans Hollander and M alte Hinselmann, used this equipment to great effect. 
Real time was used by Hansmann (1972) to perform the first intrauterine blood transfusions in the case of severe Rhesus disease (in the fetal peritoneal cavity).

Hammacher and Joachim Hackeloer (1979) demonstrated the value of routine ultrasound screening and they established the need to perform three ultrasounds on all pregnant women. ${ }^{6}$ This practice gradually spread to the whole of Europe as it was taken up by proponents such as $M$ andruzzato et al, Salvensen and Eik-N es, Levi, Z Papp, Van Geijn, Kurjak, Monni, Bonilla, De la Fuente and Carrera.

K ratochvil et al $(1967,2000)$ and E M erz (1989) were the first to introduce the use of 3D ultrasound in Europe. Constant and Besson (2005) introduced transvaginal ultrasound.

A more recent pioneer of modern echocardiography is Chaoui, who has published several papers on the inflow and outflow tract.

The use of ultrasonography during the first trimester has paved the way for embryonic medicine. The technique has enabled the in vivo study of uterine receptivity (K urjak, 1991; Kupesic, 2001), embryo implantation (Hafner and K urjak, 2011), the formation of the yolk sac (J anioux, 1991), and the study of the first stages of embryo development and early embryonic circulation (A rduini and Rizzo, 1991; Kurjak et al, 1994).

A study of fetal circulation was first performed by Campbell et al (1983) using a Doppler. Recordings of all the fetal vessels were subsequently obtained (1986). K ypros $\mathrm{Nicolaides}$ et al (1988) found a very high incidence of acidosis and hypoxia, as determined by cordocentesis, in pregnancies complicated by absent or diastolic flow . K urjak et al introduced color flow mapping into fetal studies (1987).

In the 1980s, many European authors (Wladimiroff, A rabin, Künzell, Schneider, V etter, Pardi, etc.) conducted studies on fetal blood distribution and the process of the centralization of fetal circulation.

Prenatal diagnosis emerged thanks to ultrasonography, which made it possible to detect most malformations and morphological defects. Some of its greatest exponents are Hackolöer, Hansman, Campbell, Nicolaides, M erz, Schneider, A ntsaklis and Gembruch, while B runo B rambati should be highlighted for having introduced CV S to Europe.

Biochemical tests soon caught the interest of perinatologists in Europe. The first biochemical methods for fetal monitoring were based on the study of placental products. As a result, Sellman A schheim and Bernard Zondeck discovered a protein hormone secreted by the placenta (chorionic gonadotrophin). In 1968, independent reports by $\mathrm{N}$ adler and $\mathrm{Dancis}$ first described the diagnosis of congenital errors in the fetal metabolism, which it was subsequently possible to diagnose prenatally.
During the same period, B rock, Scrimgeour and Sutcliffe (1972) confirmed the usefulness of alpha-proteins in both the amniotic fluid and the maternal serum for determining neural tube defects (NTD).

Finally, by using certain biochemical markers (AFP, PA PP-A, free-beta unit of hCG, estriol, etc.) the biochemical screening of the aneuploidies could be performed.

The relationship between increased nuchal translucency (NT) thickness and abnormal karyotype revolutionized prenatal diagnosis in the first trimester (Nicolaides et al 1992).

The controversy is still open between the defenders of biochemical screening and the supporter's ultrasonographic screening (Nicolaides et al, 1993; W ald et al, 1996).

However, from the time that $J$ ames $W$ atson and Francis Crick described the exact structure of the DNA, the explosion in molecular biology has revolutionized medical practice. Prenatal diagnosis has benefited enormously, while the prospect of embryonic and fetal gene therapy may not be as far in the future as many believe or fear.

A major advance was the introduction of preimplantation genetic diagnosis (B rambati, M onni, etc.).

The first fetoscopies proper were carried out the 1970s, but only after 1980 did the procedure become regular practice in some prenatal diagnosis centers (R odeck et al, 1980).

A fetoscopy not only provides a direct view of the fetus but also al lows biopsies of the skin-for enzymatic or other types of study (Valenti, 1972; Rodeck et al, 1980)-or the liver (R odeck et al, 1982) to be taken, as well as samples of fetal blood before labor starts (Rodeck and Campbell, 1978; Nicolaides and Rodeck, 1982). The latter enables the diagnosis of hemophilia and fetal hemoglobinopathy, the immunological study of the fetus, karyotyping by means of lymphocyte culture, and the diagnosis of heterozygosity.

Daffos et al (1983) demonstrated that it is possible to obtain fetal blood without a fetoscopy by means of cordocentesis. This research group obtained fetal blood by means of an ultrasound-guided direct puncture of the cord vessels. The efficacy of this technique was subsequently confirmed by Nicolaides et al (1986) and several Spanish perinatologists ( $P$ de la Fuente, Parra, etc.).

At present, endoscopic procedures have speeded up progress in intrauterine surgical therapy, especially in the treatment of feto-fetal transfusion syndrome.

In recent years, the preventive strategies to avoid prematurity have improved cervical ultrasound screening, the detection of fetal fibronectin and other biochemical markers, the study of inflammatory factors, etc. European sonographers also demonstrated the value of cervical length 
Development of Perinatal Medicine in Different Geographic Areas

and funnelling in making a prognosis of preterm births (A rabin 1977).

The administration of progesterone in selected groups at risk of prematurity (Nicolaides, 2001; Di Renzo, 2002) has decreased the ratio of preterm labor.

A major landmark in modern perinatal medicine was the introduction of tocolysis for treating the threat of premature labor. The effect of betamimetics for inhibiting preterm labor was published for the first time in 1961 by two groups in Europe, namely, Bishop and W outersz on the one hand, and Eskes and Hendriks on the other. The next step was the use of betamimetics during labor for intrauterine fetal resuscitation.

The new trends in tocolysis, especially the blockade of oxytocin receptors, the administration of steroids and the transfer of the mother to adequate hospitals, have improved perinatal morbimortality in Europe.

Erich Saling et al introduced a simple program for the prevention of ascending infections-the main cause of prematurity-involving the frequent measurement of the vaginal pH by the patients themselves (1994).

With regard to treating the risk and/or threat of preterm labor, new types of cerclage have been developed in recent years, such as occlusive cerclage (Carrera, 1982), early total cervix occlusion (ETCO) by Saling et al (1984) and the pessary proposed by B Arabin (1984, 1991), which was used with considerable success in Spain (Cabero and Carreras, 2006). It was designed to prevent late miscarriage or preterm birth due to cervical incompetence, whose effect is comparable to that of cerclage.

With regard to cervical ripening, in 1975 Calder introduced the clinical practice of using prostaglandins to ripen the cervix. Initially used for abortions (L ippert, 1973), they were subsequently used extra-amnially, intracervically or intravaginally in the case of an unripe cervix in order to induce labor. In Europe, the E 2 prostaglandin is generally used.

Fetal surgery has been performed in Europe by a number of researchers, such as Nicolaides, Deprest, Hecher and Gratacós, with notable success.

The efficacy and safety of laser treatment for the twintwin transfusion syndrome has also been demonstrated (Hecher, Gratacos, etc.).

The study of fetal behavior has undergone considerable development in recent years. Thanks to the studies on brain functions and the correlations of the spectrum of neuromotor abnormalities with neurocognitive outcomes (C A mielTison), it has been possible to study fetal behavior by means of $4 \mathrm{D}$ ultrasonography, which provides the most useful indicator of brain functions (K urjat et al).
Table 1: Western Europe (2011)

\begin{tabular}{lccc}
\hline & MMR* & IMR ** & NMR*** \\
\hline Austria & 4 & 4 & 2 \\
Belgium & 8 & 4 & 2 \\
Cyprus & 10 & 3 & 1 \\
Denmark & 12 & 4 & 2 \\
Finland & 5 & 3 & 2 \\
France & 8 & 4 & 2 \\
Germany & 7 & 4 & 2 \\
Greece & 3 & 4 & 3 \\
Iceland & 5 & 3 & 1 \\
Ireland & 6 & 4 & 2 \\
Italy & 4 & 4 & 2 \\
Luxembourg & 20 & 3 & 1 \\
Malta & 8 & 6 & 4 \\
Monaco & - & 4 & 2 \\
Netherlands & 6 & 4 & 3 \\
Norway & 7 & 3 & 2 \\
Portugal & 8 & 3 & 2 \\
San Marino & - & 2 & 1 \\
Spain & 6 & 4 & 3 \\
Sweden & 4 & 3 & 1 \\
Switzerland & 8 & 4 & 3 \\
United Kingdom & 12 & 5 & 3 \\
\hline Fi Materna motality & & 3 & \\
\hline
\end{tabular}

*: Maternal mortality ratio (per 100,000 live births); **: Infant mortality ratio (per 1,000 live births); ***: Neonatal mortality ratio (per 1,000 live births) (C ourtesy: WHO, UNICEF, UNFPA, WB, MMEIG)

A dvances were made in Europe in understanding the physiopathology of pre-eclampsia; thanks to the work of a number of researchers (B enedetto, 1990, etc). This al so led to major achievements in the field of inherited thrombophilias in pregnancy.

The rate of maternal mortality, barring the exceptions of Luxembourg and the United Kingdom, is below 10/ 100,000 live births, infant mortality ranges from between 3 and 6 per 1,000, and neonatal mortality is bel ow $4 / 1,000$ (see Table 1). ${ }^{17}$

\section{CENTRAL AND EASTERN EUROPE}

In addition to Russia, whose perinatal medicine evolved on a separate path for many years, this outline will deal with three countries, which as communist satellite states were relatively isolated: Hungary, Romania and Croatia. To a large extent, they are the most representative countries of this area.

\section{Russia}

In Russia the concept of perinatal medicine has been developing since 1970.

Natalia Garmasheva and Natalia Konstantinova were the pioneers.

Garmasheva introduced en Rusia the expression 'The fetus as a Patient' into clinical practice. Shealso popularized 
the expression 'muscular-cardiac reflect' (acceleration of FHR) and created the first phonocardiograph machine in 1957. N atalia K onstantinova introduced in Russia the basic principles of perinatal medicine and accelerated the clinical acceptance of new techniques such as CTG, ultrasonography, etc. to study the fetus. So that since 1980 most important maternities used this technology. From 1981 till 2000 she was the chief of Pathophysiological Department in the DO of the Research Institute of Obstetrics and Gynecology.

Distinguished perinatology professors in present-day Russia are professors: G alina Savelieva chief of Department of Obstetrics and Gynecology, Pirogov National M edical University; Vladimir Serov, President of Russian Society of Obstetrics and Gynecology and member of the Russian A cademy of M edical Sciences; A lexander Srizahakov, chief of Obstetrics and Gynecology Department of Sechenov Moscow State M edical A cademy; M ark K urcer, chief Obstetrician-Gynecologist city of Moscow, and A nton M ikhailov, Director and Chief of Saint-Petersburg M aternity Clinic.

All of them have developed activities referred to fetal state control in pregnancy and labor, maternal and perinatal mortality, implementation of the new techniques, prenatal diagnosis, fetal therapy, etc.

All of them have published hundreds of papers about the continuous improvements in perinatal medicine that have personally presented in regional, national and international congresses.

B esides of the obstetricians-perinatologists that have just been mentioned, we have to make reference to neonatol gistsperinatologists that introduced the new concepts and adequate technology for its development. A mong them, its necessary speak about: Prof Elena B aibarina, who during many years, was the chief neonatologists of Russian Federation. She introduced the bases of modern parental nutrition in neonates, and designed many of scientific and practical aspects of nursing of premature infants, organization of neonatal care, implementation evidencebased medicine and perinatal audit. Prof Nikolay Shabalov, Chief Pediatricians of M inistry of D efense, he is well known for his work about reactivity and child's adaptation to the extrauterine life and perinatal hipoxia. Prof Nikolay V olodin, he is the Rector of Pirogov Russian State Research M edical U niversity and President of the R ussian A ssociation of Perinatal M edicine. The fields of clinical and scientific activity: Postnatal adaptation, clinical diagnosis of bacterial, viral and fungal infections and neonatal resuscitacion.

Others neonatolgists of grate prestige are: Dimitry Degtyarev and Prof Dimtri Ivanov.
The sanitary model in Russia has changed considerably in the recent years. Before 1990, the Soviet U nion had a socialist model of health care with a centralized, integrated and hierarchical organization. The Government provided free health care to all citizens. The maternal and infant health care followed the same model.

The efficiency of the system started to get worse in 1980 because of an insufficient budget. As a consequence prematurity and malnutrition rates increased notably.

From 1991 post-Soviet Russia has changed to a mixed model of health care with private financing and provision running alongside with state financing and provision. Unfortunately the resulting system is very complex and inefficient.

A new reform took place in 2000, with an important investment increase. Since then there have been important improvements. However, maternal perinatal and infant mortality rates are still higher than in Western Europe.

During the last years federal resources have been transferred to the prevention programs and systems through a network of prenatal diagnosis and the creation of a National maternal-infant Health System. Thanks to the international support to the Russian civic organizations training programs for doctors, midwives and social workers have increased. Nowadays Russia has excellent training centers for maternal and infant health care professionals.

The current official maternal mortality rate is 34 per 100,000 live births (20 years ago it was 60 per 100,000), neonatal mortality is 6 per 1,000 and infant mortality goes up to 12 per 1,000. In W estern Europe only Georgia and A lbania have higher rates.

Rates of prematurity, anemia, hepatitis B, diphtheria and syphilis that have traditionally been higher than those in Western Europe are continuously coming down and immunization levels have clearly improved.

A lcoholism, smoking and tuberculosis are three factors that affect perinatal outcomes and are difficult to control. Moreover, HIV/AIDS which was practically unknown during the Soviet U nion period extended quickly after the fall of the Soviet U nion due to the increase of drugs injected intravenously.

M ortality rates vary a lot depending on regions. W hereas in big cities infant mortality rates are moderate, in the poor and peripheral regions ( $N$ orth of Caucasus, Eastern Siberia, Chukotski in the far East, etc.) are high (42 per 1,000 live births). In those regions there are no programs referred to prenatal care, family planning or reproduction assessment. U sually sanitary assistants instead of physicians or midwifes help women in labor. In many federal districts health care is provided in hospitals with few primary care resources. 
Russia has outstanding reference mother and infant hospitals, especially in big cities. The most important are: VI Kulakov Scientific Centre of Obstetrics, Gynecology and Perinatology (M oscow, Professor Suhih); DO Institute of Obstetrics and Gynecology (Saint-Petersburg, Professor Ailamazyan); Scientific Institute of Obstetrics and Gynecology Moscow Regional (Moscow, Prof K rasnopolsky); St Petersburg Maternity Clinic and Mechnikov North-W est State Medical University (SaintPetersburg, Professor K hurtslava); I vanovo National Scientific Institute of M aternity of Childhood (Central Region of Russia, Professor Maliskhina); St Petersburg Institute of Perinatology and Pediatrics of A mazov Federal Centre of Heart, Blood and Endocrinology (St. Petersburg, Professor Shlyakhto and Professor Ivanov); U ral Scientific Institute of Maternity and Babyhood Care (Ekaterinburg, Professor K ovalev), and Rostov Scientific Institute of Obstetrics and Pediatrics (Rostov, Professor Linde).

Russia also has prominent reproduction and genetics centers.

Russia has several Scientific Societies related to perinatal medicine: 'Russian A ssociation of Perinatal Medicine', 'Russian A ssociation of Obstetrics and Gynecology,' 'Russian A ssociation of Ultrasonography in Obs/Gynec,' Russian Association of Human Reproduction, etc. all of them publishing scientific magazines.

\section{Hungary}

This country has a notable history of maternal-fetal medicine. It is worth mentioning that Professor Ignaz Philipp Semmelweis (1818-1865), who was one of the most outstanding figures in the history of obstetrics in the world, thanks to his discovery of the causes of puerperal fever.

Vilmos Tauffer should also be mentioned, as he was one of the first obstetricians to set up a national central birth register in the world.

Given this historical background, obstetrics and pediatrics have always been of a high standard in the country, but perinatal medicine, as such, only began establish itself in 1960 to 1965. Influential figures in this process were Imre Zoltán, V ice-President of FIGO, who systematized the prophylactic indications for cesarean sections; Sandor Surányi, who introduced the acid-base balance analysis in the fetal blood obtained from the fetal skin vessels in 1966; D ezsö Schuler, who in 1990 introduced cytogenetic methods and chemotherapy in Hungarian pediatrics, and who also established the national network of neonatal intensive care units in Hungary; János Kiszel, who was one of the first neonatologists to set up a neonatal intensive care unit, as well as establishing high-frequency oscillatory ventilation (HFOV) in the treatment of neonatal respiratory disturbances; Laszló L ampé, who made an indepth study of fetal iodine and the metabolism of bilirubin, as a result of which he proposed new procedures for controlling hyperbilirubinemia; József Gaál, who dedicated his working life to ensuring that most births were monitored using new electronic and biochemical controls; and, finally, Zoltan Papp, who over the past 20 years has been Hungary's international face for perinatology.

Zoltan Papp introduced every aspect of prenatal diagnosis (ultrasound, cytogenetics, biochemical genetics, etc.) to Hungary. He was one of the first to perform amniocentesis, as a result of which he systematized the various types of congenital defects in a number of publications.

As a result of these combined efforts, and despite the country's economic problems, the outcomes in perinatal medicine have been of a high standard. M aternal mortality is $21 / 100,000$, neonatal mortality is around $4 / 1,000$, and infant mortality is $8 / 1,000$. Practically all pregnant women undergo prenatal screening and are assisted by health care personnel in labor.

A part from the 'Hungarian Society of Perinatal Medicine', there are two other related societies: the 'Hungarian UItrasound Society in Obstetrics' and 'Gynecology and the Hungarian A ssisted Reproduction Society,' both of which were founded by Prof Z Papp.

\section{Romania}

The 'R omanian Society of Perinatal M edicine' was founded by Prof Florin Stamatian in 1976. Three people (F Stamatian, R V ladareanu and D Pelinescu O nciul), introduced perinatal medicine techniques to the country, with special emphasis on the prenatal diagnosis of congenital defects. B etween them, they have founded the 'Romanian School of Obstetrical and Gynecological Ultrasound' (F Stamatian); established a national program for the prevention and diagnosis of fetal malformations and genetic diseases (F Stamatian, 1999); determined fetal growth curves in southern Romania (R Vladareanu, 1996); organized ultrasound courses in obstetrics and perinatal medicine (Onciul); and running courses in fetal medicine since 2007 (R V ladareanu).

Currently, F Stamatian is the coordinator of the $N$ ational Centre for Genetic Counseling and Prenatal Diagnosis. While Prof Radu V ladareanu organizes most of the international conferences on perinatal medicine that are held in Romania.

Thanks to their efforts, the main techniques in perinatal medicine have spread throughout the country. N evertheless, the national health system has severe limitations. 
The maternal mortality ratio is $11 / 100,000$ live births, the infant mortality rate is $12 / 1,000$ and neonatal mortality is $7 / 1,000$. A ccording to government reports, $90 \%$ of pregnant women undergo prenatal screening and $99 \%$ are assisted by skilled personnel in labor.

\section{Croatia}

The development of perinatal medicine in Croatia has made significant advances over the past 30 years, fundamentally due to tw o people: Prof A nte D razancic, father of perinatal medicine in Croatia, and Prof A sim K urjak, who introduced ultrasonography in Croatia and many other countries in the world, and is the country's international face of perinatal medicine. ${ }^{3}$

In 1972, Drazancic founded the Section of Perinatal Medicine of the Croatian Medical Association, which became the 'Croatian A ssociation of Perinatal M edicine' in 1992 as soon as the country gained independence. He also founded and was the first director of the Institute for Perinatal Health, an affiliate of the Department of Obstetrics and Gynecology at the University of Zagreb's School of Medicine. The Institute's associate professors included Eduard B arsï, I van K uvacic, A sim K urjak and V isnja L atin. A mong other activities intended to develop perinatal medicine in the country, the following should be highlighted: the organization of the postgraduate course in perinatology and neonatology at the School of M edicine of the University of Zagreb (1978), the first N ational Conference on Perinatal Medicine (1987) and the institutionalization of regional perinatal health care in Croatia.

However, the pioneer of ultrasound diagnosis in Croatia is Prof A sim Kurjak who has been largely responsible for the introduction of the latest technology in perinatal medicine. Together with Prof Campbell, he published the first paper on cephalometry in the B ritish M edical Journal in 1972. Since 1983, he has been organizing a university postgraduate course on ultrasound in clinical medicine, which is taught in both Croatian and English.

In 1981 he founded the 'I an Donald Interuniversity School of Medical Ultrasound,' which now has schools in countries all over the world. He subsequently organized the first meeting in Dubrovnik of the International Society 'The Fetus as a Patient' (1984). Since 1984, he has introduced a whole raft of new technologies to perinatal medicine, such as the transvaginal color Doppler technique, partly thanks to the fact that when he was the head of the UItrasonic Institute, it was a collaborator of the World Health Organization.

He was president of the 'European A ssociation of Perinatal Medicine,' 'the World A ssociation of Perinatal Medicine' and is now vice president of the 'International A cademy of Perinatal M edicine'. ${ }^{4}$
As a teacher, some of his pupils have become internationally recognized in the field. They include: Prof Ratko A ffirevic (UK), Prof Davor Jurkovic (UK), Prof Ivica Zalud (USA), Prof Sanja Kupesic (USA), Prof M laden Predanic (USA), Prof A jlana L utvica (Sweden), Prof Ratko M atijevic (Croatia), Prof M ilan Kos (Croatia), Prof B erivoj Mïskovic (Croatia) and Prof M ilan Stanojevic (Croatia). The latter was among first second-generation neonatologists in Croatia. He introduced intensive care and mechanical ventilation for newborn babies in Croatia. $\mathrm{He}$ also introduced the cryocoagulation of the avascular retina for retinopathy of prematurity, the prophylactic vitamin $\mathrm{K}$ application in newborns and the $3 \mathrm{D}$ ultrasound technique to the field of neonatology, and he has also contributed to the study of fetal behavior.

As a consequence of all of this frenetic activity, the development of perinatal medicine in Croatia has been spectacular, as a result of which the perinatal health in the country has reached extremely acceptable levels of success. This is reflected in the maternal mortality figures reported for live births of $17 / 100,000$. Perinatal mortality is $3 / 1,000$ and infant mortality is below $5 / 1,000$. Figures also suggest that all births are assisted by health care personnel.

In this area, the highest maternal mortality rates are in Georgia (67/100,000), U kraine (32/100,000) and Latvia (34/ $100,000)$. Insofar as infant mortality is concerned, Georgia has the worst rate $(21 / 1,000)$ (T able 2$)$.

Table 2: Central and Eastern Europe (2011)

\begin{tabular}{lrrc}
\hline & MMR* & IMR** & NMR*** \\
\hline Albania & 27 & 14 & 7 \\
Belarus & 4 & 6 & 3 \\
Bosnia and Herzegovina & 8 & 8 & 5 \\
Bulgaria & 11 & 12 & 7 \\
Croatia & 17 & 5 & 3 \\
Czech Rep. & 5 & 4 & 2 \\
Estonia & 2 & 4 & 2 \\
Georgia & 67 & 21 & 15 \\
Hungary & 21 & 6 & 4 \\
Latvia & 34 & 8 & 5 \\
Lithuania & 8 & 6 & 3 \\
Macedonia & 10 & 10 & - \\
Montenegro & 8 & 7 & 5 \\
Moldova & - & 16 & - \\
Poland & 5 & 6 & 3 \\
Romania & 27 & 13 & 8 \\
Russian Fed. & 34 & 12 & 6 \\
Serbia & 12 & 7 & 4 \\
Slovakia & 6 & 8 & 4 \\
Slovenia & 12 & 3 & 2 \\
Ukraine & 32 & 10 & 5 \\
\hline
\end{tabular}

IGME, 2011; *: Maternal mortality ratio (per 100,000 live births); **: Infant mortality ratio (under-five, per 100,000 live births); ***: Neonatal mortality ratio (per 1,000 live births) 
Development of Perinatal Medicine in Different Geographic Areas

\section{NORTH AMERICA}

\section{United States of America}

The first A merican society of perinatal medicine was founded in 1977 and was called the 'Society of Perinatal Obstetricians'. However, the foundations of maternal-fetal medicine had been laid in the two preceding decades; thanks to obstetricians such as Hon (1964), Quilligan (1964), Nesbitt (1969), Schifrin (1973), and neonatologists such as Virginia A pgar (1909-1974), Louis Gluck (1924-1997), L Stanley James (1924-1994) and W illiam Silverman (1917-2004). ${ }^{13}$

The rapid development of perinatal medicine in the USA undoubtedly contributed to the fact that in 1969 the A merican Board of Obstetrics and Gynecology set up a division of maternal-fetal medicine, thus making this subspecialty an officially recognized field of medical training.

How ever, the main reason for the progress made in this field is largely due to the rapid introduction of the technology to be able to study the mother-fetus relationship: CTG (in all its variants), ultrasonography (in its various modes), and prenatal diagnosis (biochemical, chromosomal, etc). The advances made in the care of premature babies have also played a crucial part in the development of this field.

Thanks to this new technology, rapid advances were made in the USA of our knowledge about maternal-fetal pathophysiology. Richard Paul and Roger Freeman should be mentioned as the pioneers of electronic fetal heart monitoring. N orman G ran and L eon Chesley should likewise be mentioned for introducing the modern treatment of preeclampsia, while John Hobbins and Rudi Sabbagha pioneered obstetric ultrasound. J ohn Gorman, V incent F reda and W illiam Pollack were responsible for the discovery of RhoGAM ; W illiam Ledger is considered the father of the study of infectious diseases in obstetrics, and William Spellacy, Oded Langer and Donald Constan were responsible for systematizing the monitoring and treatment of diabetes during pregnancy. Finally, the studies conducted by Roberto R omero were fundamental for the treatment of the risk of premature birth.

In the field of neonatology, M ary Ellen A very, Jerold Lucey and Thomas $\mathrm{H}$ Shaffer, among others, made major advances in our knowledge of the fetal lung through their discovery of the role of the pulmonary surfactant and introducing its therapeutic use.

In the last years, Prof Frank Chervenak (Weill M edical College, Cornell University of NY), has been one of the persons in charge of the International Promotion of Perinatal M edicine in the USA.
Table 3: North America (2011)

\begin{tabular}{lccc}
\hline & MMR* & IMR** & NMR *** \\
\hline Canada & 12 & 6 & 4 \\
United States of America & 21 & 8 & 4
\end{tabular}

*: Maternal mortality ratio (per 100,000 live births); **: Infant mortality ratio (under-five, per 100,000 live births); ***: Neonatal mortality ratio (per 1,000 live births) (Courtesy: WHO, UNICEF)

A perinatologist, expert in ultrasonography and medical ethics, he has invigorated and chaired several scientific societies and has been the president of the World A ssociation of Perinatal M edicine (W A PM).

A s a result of all of these advances, the level of perinatal medicine in the USA is extremely high. This is even true despite the socioeconomic differences between the Caucasian and non-Caucasian population. A ntenatal screening checks are performed on $99 \%$ of pregnant women, maternal mortality is $21 / 100,000$ live births, neonatal mortality is 4/1,000 and infant mortality is $8 / 1,000$ (Table 3 ).

The proportion of cesarean sections ranges between 23 and $35 \%$ depending on social class. Of all newborns, $8 \%$ are classified as low birth weight babies.

\section{Canada}

The state of perinatal medicine in Canada is very similar to that in the USA, although its maternal $(12 / 100,000)$ and infant $(6 / 1,000)$ mortality rates are even better than those of its neighbor.

In Canada, as in many countries around the world, obstetrics and neonatology developed along separate lines for many years before combined programs of perinatal and neonatal medicine were introduced in the 1970s. M odern neonatology began in the 1960s in Montreal under the leadership of Robert U sher, Leo Stern and Bernard Dorë. At the same time, Paul Swyer in Toronto introduced mechanical ventilation. These two cities trained the first generations of neonatologists who went on to occupy leading positions and to develop new neonatal centers, particularly in Halifax, $\mathrm{V}$ ancouver and Edmonton.

Real perinatal care combining obstetrical expertize for high risk pregnancies and neonatal expertize within the same institution was initiated in the province of Quebec in the early 1970s. The government assigned five perinatal care hospitals and closed obstetrics departments in hospitals that delivered few er than 1,500 babies a year. It was al so decided that all pregnancies delivered before 34 weeks or with special problems should be transferred to one of the five perinatal centers. This approach spread rapidly across the county.

What helped the development of this approach is the fact that in Canada there are no private hospitals, and all 
medical and hospital expenses are covered by the government.

Nowadays, every province has assigned university perinatal/neonatal centers to which the population at risk is directed. Programs are recognized by the R oyal College of Physicians of Canada with review of performance and accreditation every 4 years.

Canada has made several important contributions in the global development of perinatal care. It is w orth mentioning that historically the first exchange transfusion in a newborn baby was performed in Toronto by Dr A Ifred Hart in 1925. Paul Swyer was among the first to introduce mechanical ventilation in newborn infants and Rigatto conducted important studies on apnea, while $U$ sher provided the first real metabolic support for babies with RDS and introduced growth curves for newborns. Jack A randa and A Papageorgiou at M cGill University and Sylvain Chemtob at the $U$ niversity of $M$ ontreal pioneered studies on antenatal steroids, caffeine, ibuprofen, diuretics, the management of extremely low birth weight infants, retinopathy of prematurity and nutrition. J Sinclair at M CM aster U niversity is widely recognized for his epidemiological studies. Important follow-up studies were initiated by Fitzhardinge and more recently by Seroj Saigal and R Sauvé. In obstetrics, Richie and Ryan in Toronto, K inch and Gagnon in M ontreal, and Peddle and Linstrom in Halifax provided strong leadership in terms of patient care and education, and SK Tan introduced in vitro fertilization programs in M ontreal in the 1990s.

However, the success story in Canadian perinatal/ neonatal medicine remains the excellent organization and regionalization of perinatal care. This has been successful to the extent that in this vast country, over $85 \%$ of infants born weighing less than $1,500 \mathrm{gm}$ are delivered in one of the provincial perinatal centers. Canada currently has one of the lowest perinatal mortality rates in the world.

\section{CENTRAL AND SOUTH AMERICA (LATIN AMERICA)}

Despite the frequent economic problems experienced by the countries in this area, in addition to the limited technology available there, the level of perinatal medicine is generally fairly acceptable.

This is doubtless due to the positive influence of two large centers specialized in perinatology that have trained a large number of perinatologists over the last 40 years.

The first of these centers, located in M ontevideo (U ruguay), is the Latin A merican Center for Perinatology (CLAP), which is recognized worldwide for its work and has had a particularly strong influence on Spanish- and Portuguese-speaking obstetricians and neonatologists.
It was founded in 1970 by Prof Roberto Caldeyro Barcia who was its first director. R oberto Caldeyro, together with Hermógenes Álvarez, conducted experimental studies on uterine contractility and the relationship between uterine dynamics and the fetal heart ratio. His training in physiology, his command of scientific methodology and his experience in experimental techniques made it possible for his research work to not only revolutionize the control of labor, but also its medical supervision. $\mathrm{H}$ is research was largely responsible for the construction of the cardiotocograph.

Most Latin A merican specialists in obstetrics and perinatology were trained at this center, which works under the supervision and in collaboration with the Pan A merican Health Organization (OPS). Its current official name is the Latin A merican Center for Perinatology-Women and Reproductive Health (CLAP/SM R). Since it was set up, the people who work there have written hundreds of guides on perinatology and reproduction, as well as developing programs that have contributed to reducing the high rates of maternal and perinatal mortality in the 1950s and 1960s.

Some of the most important people to have worked at the center include Pose, Poseiro, A lthabe, M endez-B auer, Bieniarz, Schwarcz and Fescina.

D ozens of perinatologists from $L$ atin A merica and Spain were trained there (B ancalari, M onleón, Navarrete, Gallo, $M$ arinho, etc.) and many others have followed in their wake (Esteban-A Itirriba, Carrera, Clavero, Gamissans, etc.).

The second center is the $\mathrm{N}$ ational Institute of Perinatology in M exico. Founded in 1977, its first directors were Eduardo García Jurado and Samuel K archmer. M ost of Central A merica's obstetricians and perinatologists were trained while the latter was the director there. The institute's courses in fetal pathophysi ology, fetal behavior and internal fetal monitoring reached a high level. Prof J avier M ancilla is currently its director. It publishes the journal ' Perinatology and Human Reproduction'.

The ' $L$ atin A merican Federation of Perinatal M edicine Associations' (FLAMP) was founded in 1982. Emerging societies of maternal-fetal medicine from eight countries (Ecuador, Mexico, the Dominican Republic, Panama, Colombia, Peru, Bolivia and Chile) initially joined it. Subsequently, a total of 26 societies from 16 countries have become members of the Federation. Prestigious people in the field have been its president: Samuel K archmer, Dalton A vila, José Garrido, M arcelo Zugaib, A rnaldo A costa and Soubhi Kakhale. In 2010, the society was relaunched with the support of the WAPM and the IAPM at the Global Congress of $M$ aternal and Infant $H$ ealth in Barcelona. The FLA M P publishes the journal the 'L atin A merican Journal of Perinatology'. 


\section{Table 4: Central and South America (2011)}

\begin{tabular}{|c|c|c|c|}
\hline & MMR* & IMR** & NMR *** \\
\hline Antigua and Barbuda & - & 8 & 4 \\
\hline Argentina & 77 & 14 & 7 \\
\hline Bahamas & 47 & 16 & 7 \\
\hline Barbados & 51 & 20 & 10 \\
\hline Belize & 53 & 17 & 8 \\
\hline Bolivia & 190 & 51 & 22 \\
\hline Brazil & 56 & 16 & 10 \\
\hline Chile & 25 & 9 & 5 \\
\hline Colombia & 92 & 18 & 11 \\
\hline Costa Rica & 40 & 10 & 6 \\
\hline Cuba & 73 & 6 & 3 \\
\hline Dominica & - & 12 & 8 \\
\hline Dominican Rep. & 150 & 25 & 14 \\
\hline Ecuador & 110 & 23 & 7 \\
\hline EI Salvador & 81 & 15 & 6 \\
\hline Grenada & 24 & 13 & 7 \\
\hline Guatemala & 120 & 30 & 15 \\
\hline Guyana & 280 & 36 & 20 \\
\hline Haiti & 350 & 70 & 25 \\
\hline Honduras & 100 & 21 & 11 \\
\hline J amaica & 110 & 18 & 11 \\
\hline Mexico & 50 & 16 & 7 \\
\hline Nicaragua & 95 & 26 & 12 \\
\hline Panama & 92 & 20 & 9 \\
\hline Paraguay & 99 & 22 & 13 \\
\hline Peru & 67 & 18 & 9 \\
\hline Saint Lucia & 35 & 16 & 9 \\
\hline Saint Vincent & 48 & 21 & 13 \\
\hline São Tomé and Príncipe & 70 & 89 & 29 \\
\hline Suriname & 130 & 30 & 16 \\
\hline Trinidad and Tobago & 46 & 28 & 18 \\
\hline Uruguay & 29 & 10 & 5 \\
\hline Venezuela & 92 & 15 & 8 \\
\hline
\end{tabular}

*: Maternal mortality ratio (per 100,000 live births); **: Infant mortality ratio (under-five, per 100,000 live births); ***: Neonatal mortality ratio (per 1,000 live births) (Courtesy: WHO, UNICEF, UNFPA, WB, MMEIG)

In recent years, particularly significant work has been carried out by Latin A merican perinatologists specialized in fetal medicine, ultrasonography and prenatal diagnosis. In Brazil: Busamara Neme, Marcelo Zugaib, Edson N M orais, Francisco M auad, A nibal Faundes, Eduardo Isfer, Renato M oreia, A ndres L uis Fonseca and J osé J unqueira. In A rgentina: M iguel M argullies, Enrique Gadow, Liliana V oto, L uis Prudent, Lucas Otaño, M ario Palermo, M iguel L ardía, R oberto K ekiklián, etc. In Chile: Waldo Sepúlveda, Jorge Fabres, José Luis Tapia, Ricardo Uauy, Ramiro M olina, etc. In M exico: Samuel K archmer, Sara Frías, Pedro Beltrán, etc. In U ruguay: A na Bianchi, Justo Alonso, Claudio Sosa, R afael B ustos, J ose L Peña, Ricardo Fescina, José Enrique Pons, Ricardo Schwarcz, etc. In Colombia: Juan Carlos Bello, Iván Ortiz, Andrés Sarmiento, etc. In Paraguay: Antonio M Ruoti, Arnaldo A costa, Ramón Battaglia. In Cuba: U baldo Farnot. In Peru: Alfredo Guzmán. In V enezuela: Carlos B ermudez. In B olivia: Carlos Futchner.
$M$ aternal mortality, which 50 years ago was in the region of 250/100,000 live births is now around 50 to 100/100,000 in most countries (A rgentina, Chile, Costa Rica, M exico, etc.), although in others it is in excess of $100 / 100,000$ (Guatemala, Bolivia, Guyana, Jamaica, Honduras and the Dominican Republic). In Haiti, it is over 350/100,000.

Over the past 20 years, perinatal mortality has dropped from 50/1,000 live births to 20-30/1,000 in M exico, Cuba, U ruguay, etc. However, it remains high in countries such as $\mathrm{H}$ aiti and Guatemala. Infant mortality has dropped from $55 / 1,000$ in 1975 to $15 / 1,000$ at present (see Table 4).

Prenatal control is performed on 85 to $90 \%$ of the population. The use of ultrasound has become widespread, while hospital births are as high as 75 to $80 \%$.

\section{AFRICA}

With the exception of a few countries such as Ethiopia, A frica had been subject to colonial rule until 1950 to 1960 , when it gradually began to be decolonized. U ntil then, the occupying powers had been responsible for organizing health care services, which were generally rudimentary and poorly coordinated. However, a considerable number of hospitals continued to be managed by colonial health care personnel.

On paper, the independence of these countries improved the state of health care through the setting up of national heal th care systems, which largely survived thanks to foreign aid (excolonial governments, WHO, the Red Cross, foundations in the West, NGOs and contributions from churches). Thus, the Catholic Church continues to run 990 hospitals, 6,000 health centers, 800 orphanages and 500 AIDS clinics in A frica. Over 60,000 people work as health care workers through such organizations.

However, in recent years, particularly since 1980, governments have been taking responsibility for health care, especially in the field of maternal and infant health, by establishing programs and setting targets. This has also led to the gradual organization of obstetricians and pediatricians into national societies of obstetrics and pediatrics. How ever, it has taken a long time for the concept of perinatology to become widely acknowledged. This explains why the first association on the continent of this subspecialty (A frican A ssociation of Perinatal M edicine) was not created until 2010. M oreover, it was only set up thanks to the pressure exerted by the 'W orld A ssociation of Perinatal M edicine'. The founding ceremony took place in Barcelona at the Global Congress of $M$ aternal and Infant Health, promoted by $M$ atres $M$ undi, which is an NGO that acts as a cooperation agency for most international societies of 


\begin{tabular}{|c|c|c|c|}
\hline \multicolumn{4}{|c|}{ Table 5: Africa (2011) } \\
\hline & MMR* & IMR ** & NMR*** \\
\hline Algeria & 97 & 30 & 17 \\
\hline Angola & 450 & 158 & 43 \\
\hline Benin & 350 & 106 & 31 \\
\hline Botswana & 160 & 26 & 11 \\
\hline Burkina Faso & 300 & 146 & 34 \\
\hline Burundi & 800 & 139 & 43 \\
\hline Cameroon & 690 & 127 & 33 \\
\hline Cape Verde & 79 & 21 & 10 \\
\hline Central African Rep. & 890 & 164 & 46 \\
\hline Chad & 1.100 & 169 & 42 \\
\hline Comores & 280 & 79 & 32 \\
\hline Congo & 560 & 99 & 32 \\
\hline Ivory Coast & 400 & 115 & 41 \\
\hline RD Congo & 540 & 168 & 47 \\
\hline Djibouti & 200 & 90 & 33 \\
\hline Egypt & 66 & 298 & 7 \\
\hline Equatorial Guinea & 240 & 118 & 37 \\
\hline E ritrea & 240 & 68 & 21 \\
\hline Ethiopia & 350 & 77 & 31 \\
\hline Gabon & 230 & 66 & 24 \\
\hline Gambia & 360 & 101 & 34 \\
\hline Ghana & 350 & 78 & 29 \\
\hline Guinea & 610 & 126 & 39 \\
\hline Guinea-Bissau & 790 & 161 & 44 \\
\hline Kenya & 360 & 73 & 27 \\
\hline Lesotho & 620 & 86 & 37 \\
\hline Liberia & 770 & 78 & 27 \\
\hline Libya & 58 & 16 & 10 \\
\hline Madagascar & 240 & 62 & 23 \\
\hline Malawi & 460 & 83 & 27 \\
\hline Mali & 540 & 176 & 49 \\
\hline Mauritania & 510 & 112 & 40 \\
\hline Mauritius & 60 & 15 & 9 \\
\hline Morocco & 100 & 33 & - \\
\hline Mozambique & 490 & 103 & 34 \\
\hline Namibia & 200 & 42 & 18 \\
\hline Niger & 590 & 125 & 32 \\
\hline Nigeria & 630 & 124 & 39 \\
\hline R wanda & 340 & 54 & 21 \\
\hline Senegal & 370 & 65 & 26 \\
\hline Seychelles & - & 14 & 49 \\
\hline Sierra Leone & 890 & 185 & 49 \\
\hline Somalia & 1.000 & 180 & 50 \\
\hline South Africa & 300 & 47 & 19 \\
\hline South Sudan & - & 121 & 38 \\
\hline Sudan & 730 & 86 & 31 \\
\hline Swaziland & 320 & 104 & 35 \\
\hline Tanzania & 460 & 68 & 25 \\
\hline Timor & 300 & 54 & 24 \\
\hline Togo & 300 & 110 & 36 \\
\hline Tunisia & 56 & 279 & 9 \\
\hline Uganda & 310 & 90 & 28 \\
\hline Yemen & 200 & 77 & 32 \\
\hline Zambia & 440 & 83 & 27 \\
\hline Zimbabwe & 570 & 67 & 30 \\
\hline
\end{tabular}

*: Maternal mortality ratio (per 100,000 live births); **: Infant mortality ratio (under-five, per 100,000 live births); ***: Neonatal mortality ratio (per 1,000 live births) (Courtesy: WHO, UNICEF)

perinatal medicine. Following the foundation of this first Pan-A frican association, other national ones were set up.

Some of the factors that cast a shadow over perinatal medicine in A frica are the high number of teenage pregnancies (between 40 and $70 \%$, depending on the

country); the large number of abortions in unsafe conditions (18 million each year); female genital mutilation; and the high rate of urinary fistulae due to obstetric complications (between 50,000 and 100,000 new cases each year).

Despite foreign aid, maternal, perinatal and infant mortality rates in A frica are the highest in the world.

M aternal mortal ity is as high as $620 / 100,000$ live births, although in sub-Saharan regions it can reach 900/100,000, with some countries clearly exceeding this figure, as is the case of Chad (1,100), Guinea-Bissau (790) and the Central A frican Republic (890).

Perinatal mortality is al so extremely high: 100/1,000 live births, with a significant increase in sub-Saharan A frica: 140 to $160 / 1,000$ live births.

It is estimated that half of the mothers and children who die in the perinatal period in the world are A frican (Table 5).

There is a similar pattern in infant mortality (under 5 years of age), which is $121 / 1,000$ in A frica as a whole, but as high as 172/1,000 in the sub-Saharan region.

M oreover, these figures are probably far off the mark as they are mere estimates given that the collection of statistics in A frica is somew hat wanting (absence of death certificates, subregisters, negligence, etc.). According to UNICEF, $70 \%$ of births are not registered.

In fact, only $40 \%$ of births take place in a health care establishment, al though in the sub-Saharan area this figure drops to $20 \%$ (8\% in Ethiopia).

Women die as a result of hemorrhages $(25 \%)$, sepsis (15\%), pre-eclampsia (12\%), obstructed labor (8\%), abortions (12\%) and other direct or indirect causes (20\%) such as malaria, tuberculosis and AIDS.

The ultimate reason for this dramatic situation is poverty ( $45 \%$ of the population lives on less than a dollar a day), which results in hunger and illness, and substantially reduces the possibility of proper health care. However, there are also cultural, physical and organizational barriers that prevent pregnant women from reaching health care centers. It should be taken into account that $80 \%$ of the population in A frica lives in rural areas where hospitals are few and far between, and are badly equipped; $75 \%$ of them do not have electricity or running water. However, one of the biggest determining factors is the lack of doctors, midwives and nurses. In A frica there is a doctor for every 20,000 inhabitants (one for every 50,000 in sub-Saharan Africa) and the continent only has one nurse or midwife for every 1,000 inhabitants, with this figure dropping to one for every 5,000 in the sub-Saharan region. The number specialists in obstetrics and pediatrics is down to a bare minimum, while, the subspeciality of perinatology is still almost unknown.

Perinatal technological resources in A frica are very scarce and generally not put to their best use. For example, the use of obstetric ultrasonography, which was introduced 
fairly early on (1969) in A frica, is extremely erratic depending on the area. M oreover, A frica is without a doubt the continent where the least ultrasound scans are performed.

In both $\mathrm{N}$ orth and South A frica, there is an acceptable use of ultrasound scans, but in sub-Saharan A frica they are practically unknown. Their use depends on the money invested in health by each government. Thus, for example, in countries such as South A frica, Gabon, Botswana, Seychelles, M orocco and Egypt, considerable investments are made, while the amount invested in RD Congo, Eritrea, the Central A frican Republic, Ethiopia and Sierra Leona is minimal. Therefore, while there is a satisfactory level of monitoring during pregnancy in North and South A frica, where $88 \%$ of the urban population undergoes at least one scan during pregnancy, in the sub-Saharan region only $20 \%$ of pregnant women in cities and $2 \%$ in rural areas are examined using an ultrasound scan.

The same is true of prenatal diagnosis (biochemical or cytogenetic), which is virtually unknown.

The introduction of modern technologies used in perinatal medicine in A frica, both in the field of obstetrics (ultrasound scan, CTG, Doppler, etc.) and neonatology (resuscitation equipment, etc.) has run into one basic problem: the lack of training of health care workers. Only a very few of them receive any regulated theoretical and practical training, and quality controls by governments simply do not exist.

Due to this lack of information, all of these techniques, and the ultrasound scan in particular, have caused new problems, such as unnecessary surgical operations as a result of the misguided interpretation of images or the monitoring of pregnancies only using ultrasound scans, as a result of which all other medical examinations-such as taking blood pressure readings-are dismissed. This is especially common in the upper echel ons of society with greater spending power.

Despite the above, the situation is gradually getting better. $M$ aternal and perinatal mortality figures have stabilized and in some areas they have even improved. Scientific output (which was nonexistent 20 years ago) is growing quickly. N ew scientific journals are being published and over the past 5 years A frica has contributed over 500 papers about perinatal medicine that have been published in both national and international journals. Furthermore, a steady increase in the number of associations of perinatal medicine can be observed, as well as ones specialized in ultrasonography (the M editerranean and A frican Society of Ultrasound, the W est A frican M edical UItrasound Society, and the South A frican Society of UItrasound in Obstetrics and Gynaecology). With regard to schools of perinatal medicine, there are very few but new ones are being opened in Tanzania, Rwanda, Egypt, etc. The role played in the field of obstetric ultrasonography by the Ian Donald School of M edical UItrasound cannot be underestimated, with new branches having been created in Sudan, Egypt, Tunisia, Libya, Cameroon G hana and Ethiopia.

\section{ASIA}

The development of perinatal medicine in A sia has varied greatly depending on the areas and countries being examined. In objective terms, the contrast in its evolution can be clearly broken down by examining the three biggest countries on the A sian continent: Japan, China and India. To a certain extent, the other countries in A sia drew on the scientific sources of these three countries for many years.

\section{Japan}

Since 1950, as a result of young people emigrating from the countryside to the city and the country's rapid industrialization, together with the great technological progress made in all fields, massive social changes took place that had repercussions on perinatal medicine. ${ }^{7}$ One example would be that home births no longer take place. Thus, while 60 to $70 \%$ of women gave birth in their homes between 1900 and 1950, with maternal mortality rates in the range of 200 to $400 / 100,000$ live births, from the 1950s onward (19512000) the proportion of hospital births rose to $99.8 \%$, as a result of which maternal mortality rates gradually dropped to reach $6.3 / 100,000$ by 2000 . As can be seen below from the latest figures published (2011), Japan has the best ratios in the world: 5/100,000 live births (Graph 1).

Other factors to be taken into account are: the biophysical and biochemical monitoring of all births, the increase (36 months) in the interval between births, the decrease in the number of children per woman, etc. ${ }^{8}$

A similar thing has happened with perinatal mortality (Graph 2). In 1950, with only $4.6 \%$ of women giving birth in hospitals the perinatal mortality rate was $46.6 / 1,000$ of live births, while by 2009 when $99.3 \%$ of women gave birth

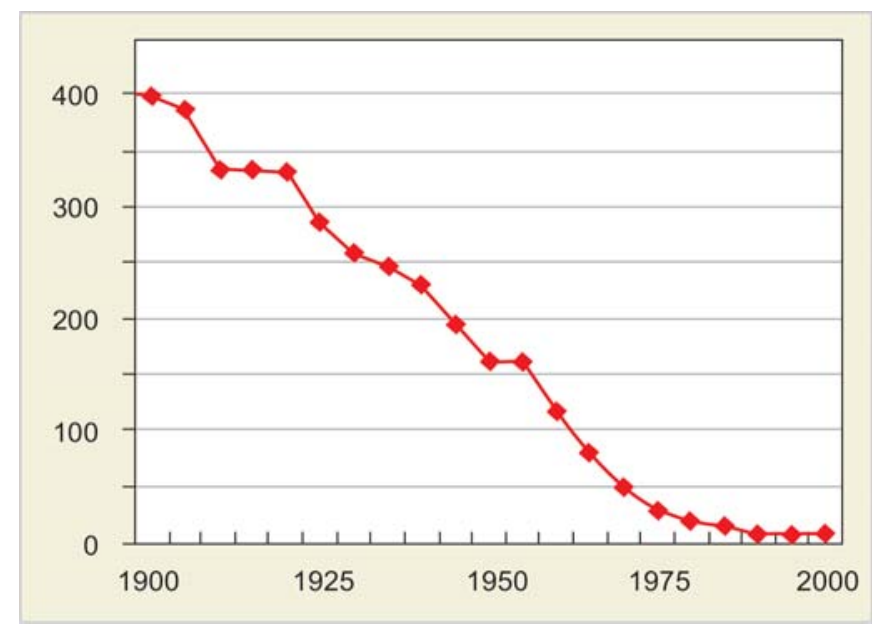

Graph 1: Evolution of maternal mortality in Japan (from K Maeda, 2000) 


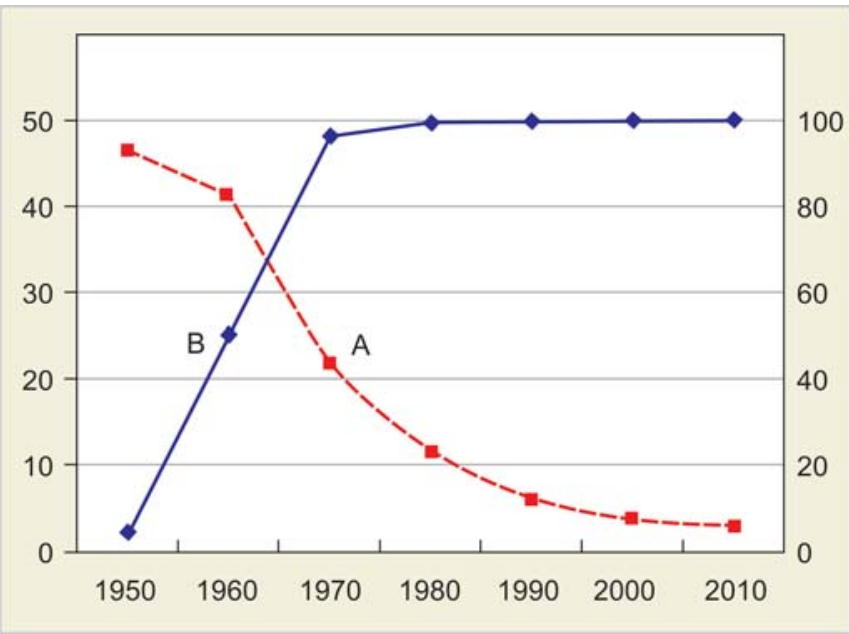

Graph 2: Perinatal mortality and hospitalary births (from K Maeda): (A) Perinatal mortality, (B) \% of hospital births (2010)

in health care institutions; perinatal mortality had dropped to $2.9 / 1,000$. G raph 2 shows that there is a strong correl ation between hospital births and the drop in perinatal mortality.

As far as infant mortality is concerned, it is the lowest in the whole of the continent: Three per 1,000.

Although improved economic conditions indirectly result in improvements in perinatal mortality, similar improvements have not always been seen in neonatal mortality. The factor that directly contributes to reductions in maternal and perinatal mortality is timely and appropriate medical intervention for the mother, fetus and neonate. Therefore, perinatologists ensure that their medical knowledge is up-to-date to enable them to provide mothers and babies with the best possible medical care.

Since 1949, J apan has had two associations of obstetrics and gynecology with sections devoted to perinatal medicine: the 'J apan Society of O bstetrics and Gynecology' (JSOG), founded by Prof Shinoda, and the 'Japan A ssociation of Obstetricians and Gynecologists' (JAOG), whose first president was Prof Taniguchi. The two societies work alongside each other. A further two societies were also set up: the 'J apan Society of Perinatal and N eonatal M edicine' (JSPNM ), which was founded in 1965 and chaired by Prof Takatsu, and the 'J apan Society of Perinatology,' which was founded in 1983 and chaired by Prof Sakamoto. These two societies merged to form a single society in 2006.

In 1978, Prof K M aeda founded the 'J apan Society of M aternal and Fetal M edicine' (JSM FM), which organizes congresses in both J apan and Taiwan. Finally, in 2003, Prof Nakano founded the 'J apan Society of Fetal Therapy'. It should also be highlighted that as far back as 1958, a group of neonatologists (Takai, Otubo, Ogawa, Saito, etc.) set up the 'J apan Society for Premature and N ewborn M edicine'.

The first International Congress of Perinatal M edicine (1991) took place in Tokyo presided by S Sakamoto, and also the foundation of W orld A ssociation of Perinatal M edicine (W A PM ). ${ }^{14,18}$

Given the country's huge technological capacity, in addition to the money spent by some of its companies (Toshiba, Aloka, Hitachi, etc.) on biological and medical engineering, Japan has not only exported ultrasound and CTG equipment around the world, but has also made it possible for J apanese perinatologists to reach a high level of understanding about obstetric pathophysiology, as reflected in an extensive and widely recognized list of publications. ${ }^{11}$ J ust by way of example, it is worth mentioning professors Sakamoto, M aeda, Terao, Y amanouchi, Nakano, Takeuchi Takeda, Tanaka, Nakamura, Nishida, Ikenoue, Taguchi, Ogawa, K wok Ming, Y oun $\mathrm{Ha}, \mathrm{Wu}$, Chiba, Kawabata, Okai, Baba, Pooh, Fujiwara, Guohong, Chan and Chen, etc.

The milestones in the history of Japan's perinatal medicine includes the dissemination by the JAOG of the idea of fetal monitoring using simple inexpensive machines, which has managed to significantly reduce severe neonatal asphyxia, perinatal mortality and cerebral palsy after birth. Likewise, the official registries for recording congenital abnormalities (1972), the program to prevent vertical mother-child hepatitis B (1985) and the reinstatement of the damaged perinatal care system following the tsunami that destroyed Tôhoku in 2011 are also worth pointing out.

\section{China}

China's national health care system and, therefore, the development of its perinatal medicine, has made considerable progress over the years. The country has 900 million inhabitants with a high population density and a rural population of $80 \%$.

B etween 1950 and 1965, considerable efforts were made to westernize medicine, and obstetrics and pediatrics in particular, although so-called traditional Chinese medicine still persisted. Following what has become known as the Cultural Revolution, traditional medicine underwent a resurgence with the appearance of 'barefoot doctors'. Who were sent out from universities into rural areas after receiving predominantly traditional training.

In the 1980s, a major program was started to improve health care in rural areas. A number of new qualifications were created that ranged from the health aide (2 years' training); to the paramedic (2-3 years' training), which included midwives and nurses; the health worker (3-6 months' training), whose job it was to keep the environment healthy; and the part-time health worker (1-3 months' training) for vaccination programs. The construction of new schools of medicine was speeded up, thus increasing the 
number of trained general practitioners with a good grounding in perinatology. A s a result of this program, there was one doctor for every 5,000 inhabitants, 26 nurses for every 100,000 inhabitants and six midwives for every 100,000 inhabitants. Furthermore, almost all of the country's 2,000 districts have at least one hospital and 200,000 small primary heal th care units have been created. The improved economy, the introduction of new industrial and agricultural technologies, and better transport systems has also helped to eradicate severe malnutrition.

Despite these advances, Chinese medical practice continues to pursue traditional procedures, which still form part of the curriculum of medical qualifications. Thus, for example, acupuncture and moxibustion are still widely used in obstetrics today. This latter technique consists in stimulating the points common to acupuncture using the heat generated by burning a herb called 'Artemisia vulgaris'. A pparently, it can be used for spontaneously turning babies out of breech position.

As a result of the government's one-child policy, the birth rate has now decreased considerably, and with it maternal and perinatal mortality. The reported maternal mortality rate is $37 / 100,000$, perinatal mortality is $40 / 1,000$, neonatal mortality is $4 / 1,000$ and infant mortality is $15 /$ 1,000 . It would seem that $89 \%$ of pregnancies undergo prenatal tests and that $96 \%$ of births are assisted by health care personnel.

It should be remembered that chorionic villus sampling (CVS) as a form of prenatal diagnosis became common practice in 1975; thanks to a team of doctors at Tietgung Hospital. They performed a transcervical aspiration technique.

A s a consequence of the one-child policy, the ultrasound scan has developed considerably over the past 30 years as a way of finding out the sex of the fetus at an early stage. In many instances, it was a used with the intention of having an abortion if the fetus was female.

Some Chinese perinatologists, such as Tao Duan, B osun, LZ D u, X iaoping L 00, Ituixia Y ang, RY Pang, Tak Y eung L eung, L uming Sun, ZC Xv, Jian Xing Zhu and Dezhi M u, have highlighted this on the international stage in the last few years.

There are currently a number of scientific societies of perinatal medicine in China such as the 'C hinese Perinatal Society' and the 'Shanghai Perinatal Society'.

\section{India}

As a result of British domination, India has developed a western style of perinatal medicine. G raduates of medicine can do a 2-year postgraduate course in obstetrics and gynecology, followed by one more year if they wish to subspecialize in perinatal medicine. However, university curricula include the teaching of traditional medicine, especially what is called ayurvedic medicine. The influence of this type of medicine increased considerably from the time of the country's independence, with the result that it now forms part of $65 \%$ of programs at medical schools.

The great inequalities in income, ethnic origin, castes, gender and geographic origin have hindered the development of a fair and rational health care system. This has happened despite the fact that over the past few years great technological advances have been made in all fields, which in theory should have improved the state of the population's economy and health. India's industry covers the country's demand for ultrasound scanners and cardiotocography at a low cost as well as other medical and surgical equipment.

There are various societies of perinatal medicine and Indian perinatologists take an active part in international conferences of perinatal medicine, especially those run by the Federation of A sia and Oceania Perinatal Societies (FAOPS).

Some obstetricians and pediatricians who have immigrated to the USA in the past and reached positions of responsibility there are now contributing to improving perinatology in India. They not only send donations but also prepare and direct specific programs (neonatal resuscitation and vaccination programs, for example).

The ' $N$ ational N eonatology Forum' in collaboration with some A merican pediatricians, particularly Prof Vidyasagar (director and professor of neonatology in the College of Medicine at the University of Illinois at Chicago), have trained over 100,000 health care workers in neonatal resuscitation. In short, the credit for modernizing the care of the newborn in India could be attributed to this team.

M aternal mortality in India is very high: $200 / 100,000$ live births. M aternal malnutrition is a cold fact of life in large regions of this vast country. One in every three pregnant women is underweight.

Infant mortality is extremely high. Every year, 2.1 million children under the age of 5 die. The official ratio is $61 / 1,000$.

It is difficult to ascertain exact perinatal mortality rates, as still born babies and those that die shortly after birth are not usually registered, but the figure probably does not fall below $100 / 1,000$, although the latest official figures say that neonatal mortality is $32 / 1,000$. Deaths are generally due to pneumonia, diarrhea and above all to malnutrition. A total of $30 \%$ of all newborns are underweight.

Government spending on public health is 1.1\% of GDP. A s a result of the latest restrictions imposed by government, the country's health care network is increasingly less efficient, which means that prenatal care and hospital births 


\begin{tabular}{|c|c|c|c|}
\hline \multicolumn{4}{|c|}{ Table 6: Asia (2011) } \\
\hline & MMR* & IMR ** & NMR *** \\
\hline Afghanistan & 460 & 101 & 460 \\
\hline Armenia & 30 & 18 & 30 \\
\hline Azerbaijan & 43 & 45 & 43 \\
\hline Bahrain & 20 & 10 & 20 \\
\hline Bangladesh & 240 & 46 & 240 \\
\hline Bhutan & 180 & 54 & 180 \\
\hline Brunei & 24 & 7 & 24 \\
\hline Cambodia & 250 & 43 & 250 \\
\hline China & 37 & 15 & 37 \\
\hline Korea & 81 & 33 & 81 \\
\hline Egypt & 66 & 21 & 66 \\
\hline India & 200 & 61 & 200 \\
\hline Indonesia & 220 & 32 & 220 \\
\hline Iran & 21 & 25 & 21 \\
\hline Iraq & 63 & 38 & 63 \\
\hline J apan & 5 & 3 & 5 \\
\hline J ordan & 43 & 21 & 43 \\
\hline Kazakhstan & 51 & 28 & 51 \\
\hline Kuwait & 14 & 11 & 14 \\
\hline Kyrgyzstan & 71 & 31 & 71 \\
\hline Laos & 470 & 42 & 470 \\
\hline Lebanon & 25 & 9 & 25 \\
\hline Malaysia & 29 & 7 & 29 \\
\hline Maldives & 60 & 11 & 60 \\
\hline Mongolia & 63 & 31 & 63 \\
\hline Myanmar & 200 & 62 & 200 \\
\hline Nepal & 170 & 48 & 170 \\
\hline Palestine & 64 & 22 & 64 \\
\hline Oman & 32 & 9 & 32 \\
\hline Pakistan & 260 & 72 & 260 \\
\hline Philippines & 99 & 25 & 99 \\
\hline Qatar & 7 & 8 & 7 \\
\hline Rep. Korea & 16 & 5 & 16 \\
\hline Saudi Arabia & 24 & 9 & 24 \\
\hline Singapore & 3 & 3 & 3 \\
\hline Sri Lanka & 35 & 12 & 35 \\
\hline Syria & 70 & 15 & 70 \\
\hline Tajikistan & 65 & 63 & 65 \\
\hline Thailand & 48 & 12 & 48 \\
\hline Turkey & 20 & 15 & 20 \\
\hline Turkmenistan & 67 & 53 & 67 \\
\hline United Arab E mirates & 28 & 7 & 12 \\
\hline Uzbekistan & 28 & 49 & 28 \\
\hline Vietnam & 59 & 22 & 59 \\
\hline
\end{tabular}

*: Maternal mortality ratio (per 100,000 live births); **: Infant mortality ratio (under-five, per 1,000 live births); ***: Neonatal mortality ratio (per 1,000 live births) (Courtesy: WHO, UNICEF)

are not available to most of the population. Only 50 to $60 \%$ of pregnant women receive any kind of prenatal treatment, and only $40 \%$ are assisted by qualified health care personnel in labor.

Some of India's internationally recognized perinatologists include T Bannejes, Ranjun Kumar, Pejaves, Sas Gupta, Neelam K ler, M Singh, A Bang, NR B hasdary, A K Deorari and Chandhari, etc.

Some A sian countries have much higher maternal mortality rates than China, Japan and India. ${ }^{12}$ Thus, for example, the figures for A fghanistan, Laos and Cambodia are 460, 470 and 250 respectively (Table 6).
The highest infant mortality rates can be observed in A fghanistan (101) Pakistan (72) and Tajikistan (63).

Reliable perinatal mortality rates are not published, but official records show that the highest neonatal mortality rates are in A fghanistan (36), M yanmar (42) and Pakistan (36).

\section{OCEANIA}

\section{Australia}

Over the past 30 years, A ustralia has built up an extremely satisfactory national health care system whose levels of perinatal mortality are frankly excellent. Thus, the figures for maternal mortality are 7/100,000 live births and infant mortality is $5 / 1,000$. Perinatal mortality is barely $6 / 1,000$.

All pregnant women undergo prenatal controls and absol utely all births are assisted by skilled staff in a hospital environment.

Between 1961 and 1963, Liley developed a systematic procedure for the diagnosis, prognosis and treatment of erythroblastosis fetalis (amniotic fluid spectrophotometric scan, Liley Scheme, intra-abdominal blood transfusion, etc). In 1973, K ossoff and Garrett demonstrated the benefits of gray-scale ultrasonography and in 1975 they designed the Octoson scanner.

\section{New Zealand}

The country also has a good track record in perinatal medicine. M aternal mortality is $15 / 100,000$ of live births, infant mortality is $6 / 1,000$ and perinatal mortality is $6 / 1,000$.

It has an acceptable level of technol ogical development.

Sir Graham Liggins, was one of New Zealand's most highly respected and internationally renowned medical research scientists. He showed that giving steroids to w omen experiencing early labor could accelerate infant lung development enough to enable premature newborn babies to breathe independently. The occurrence of RDS following the antepartum administration of betamethasone to the mother could be reduced from 24 to $4.3 \%$.

Perinatologists in the geographical region of Oceania, together with their colleagues in neighboring A sian countries founded the 'Federation of A sia and Oceania Perinatal Societies' (FA OPS), which holds a congress every 2 years and has been a key player in the development of maternal and fetal medicine in the region. The Society's members come from A ustralia, B angladesh, Hong Kong, India, Japan, K orea, M alaysia, M ongolia, N epal, N ew Zealand, Pakistan, Philippines, Singapore, Sri Lanka, Taiwan and Thailand. Its first chairman was Prof S R atnam from Singapore. Some of the most prominent members of this community of perinatologists are: G Thornurny J 
Table 7: Oceania (2011)

\begin{tabular}{lccc}
\hline & MMR* & IMR** & NMR *** \\
\hline Australia & 7 & 5 & 3 \\
Cook Islands & 12 & 10 & 5 \\
Fiji & 26 & 16 & 8 \\
Marshall Islands & - & 26 & 12 \\
Kiribati & - & 47 & 19 \\
Micronesia & 100 & 42 & 17 \\
Nauru & - & 40 & 22 \\
New Zealand & 15 & 6 & 3 \\
Niue & - & 21 & 10 \\
Palau & - & 19 & 9 \\
Papua New Guinea & 230 & 58 & 23 \\
Samoa & 100 & 19 & 8 \\
Solomon Islands & 93 & 22 & 10 \\
Tonga & 110 & 15 & 8 \\
Tuvalu & - & 30 & 14 \\
Vanuatu & 110 & 13 & 7 \\
\hline
\end{tabular}

*: Maternal mortality ratio (per 100,000 live births); **: Infant mortality ratio (under-five, per 1,000 live births); ***: Neonatal mortality ratio (per 1,000 live births) (Courtesy: WHO, UNICEF, UNFPA)

Robinson and $V Y u$ (A ustralia), D B onam, C respingny and P Gluckman (New Zealand), T B annerjee and RK Pejaver (India), R Hariadi (Indonesia) RL Tambyraja (Singapore), $K$ Chaturachinda and V airojananavong (Thailand) Z Butta (Pakistan), S Sakamoto, H Tabakayashi, K M aeda, T Ikenoue, Tgutsui (Japan), TT Hsieh (Taiwan), Bashels (Bangladesh), WW Sumpiaico, C A mirante (Philippines) and EM Symmonds (M alaysia).

There are ostensible differences between the various countries in the continent. While A ustralia and N ew Zealand have extremely acceptable ratios of maternal, neonatal and infant mortality, the figures in other countries such as Samoa, Tonga and $V$ anuatu are extremely high (Table 7).

\section{ACKNOWLEDGMENT}

The author expresses sincere gratitude to: Chiara B enedetto (from Italy), Robert L B rent (from USA), F rank Chervenak (from USA), A sim Kurjak (from Croatia), Kazuo Maeda (from J apan), A nton V M ikhailov (from Russia), Giovanni M onni (from Italy), Takashi O kai (from Japan), A postolos Papageorgiou (from Canada), Zoltan Papp (from H ungary), Ola Didrik Saugstad (from Norway), Radu Vladareanu (from Romania), V incenzo D'A ddario, for their excellent contribution to this article.

\section{REFERENCES}

1. Carrera JM. The technological devel opment of fetal surveillance: A long history. In: Carrera J M, Chervenak FA, K urjak A (Eds). Controversies in perinatal medicine. The fetus as a patient. Nashville, TN : Parthenon Publishing 2003:3-17.
2. Cosmi EV . A perspective on perinatal medicine. In: K urjak A, Chervenak $F$ (Eds). Textbook of perinatal medicine (2nd ed). A bingdon: Informa Healthcare 2006;1:X Ii.

3. Drazancic A, Kurjak A. Hrvatska perinatologija: Proslost, sadasnjost I buducnost: Gynaecol Perinatol 2002;11:53-68.

4. International A cademy of Perinatal Medicine. History, organization and activities. B arcelona: M atres M undi, 2008.

5. Kerr JMM, Johnston RW, Philips MH. Historical review of B ritish obstetrics and gynecology, 1800-1950. London: Churchill Livingstone 1954:35-45.

6. Levi S. The history of ultrasound in gynecology 1950-1980. Ultrasound M ed Biol 1997;23(4):481-552.

7. $M$ aeda $K$. W hy the perinatal mortality rate in J apan is very low: $M$ essage to European perinatologists. In: Kurjak A (Ed). Textbook of Perinatal Medicine. UK: Parthenon, 1998;1: 195-203.

8. Maternal and Child Health Division, Children and Families B ureau, M inistry of $\mathrm{H}$ ealth and W elfare. Statistics relating to maternal and child health in J apan (1949-1969), maternal and child heal th statistics of J apan (1993-2010), Tokyo, B osi-H oken J igyodan p123, column 2, range 18 (J apan).

9. N orton M. N ew evidence on birth spacing: Promising findings for improving newborn, infant, child and maternal health. Int J Gyecol Obstet 2005;89:51-56.

10. O'Dowd MJ, Philip EE. The history of obstetrics and gynaecology. Candorth, UK : Parthenon Publishing 1990 p113, column 1, range 5 (W estern Europe).

11. Okai T. Intrapartum management guidelines based on fetal heart rate pattern classification. J Obstet Gyneco Res 2010;36: 925-28.

12. Karim SM M, Tan KL. Problems in perinatology proceedings of the 1st A sia Oceania Congress of Perinatology, University of Singapore, K andang K erbau H ospital, R epublic of Singapore: 1979 N ov:25-28.

13. Q uilligan EJ. Perinatal medicine in U nited States. In: K urjak A, Chervenak $F(E d s)$. Textbook of perinatal medicine (2nd ed). A bingdon: Informa Healthcare 2006; XX V III.

14. Sakamoto $S$. M emories of the W orld A ssociation of Perinatal Medicine. In: Kurjak A, Chervenak F (Eds). Textbook of perinatal medicine (2nd ed). A bingdon: Informa Healthcare 2006; XXX XiV .

15. Saling E. A rabin B. Historic landmarks of perinatal medicine in Obstetrics. J Perintal Med 1988;16:5-21.

16. Skolov SJ. History of Ultrasound. In: de V iegler M, Holmes JH, Kazner E, K ossof G, K ratochwill AD (Eds). Handbook of clinical ultrasound. New Y ork: Willey 1978:111-12.

17. UN M aternal M ortality Estimation G roup: Estimates of maternal deaths and lifetime risk of maternal death, 2010:25-30.

18. W orld A ssociation of Perinatal M edicine: History, organization and activities. Barcelona: Secretary General's Office; 2005 p124, column 2, range 2 .

\section{ABOUT THE AUTHOR}

\section{José M Carrera}

President of M atres M undi, E meritus Professor, Department of Obstetrics and Gynecology, Dexeus U niversity Institute, B arcelona, Spain

CorrespondenceAddress: M atres M undi: Londres 6, 08029 Barcelona Spain, Phone: (34) 934190015, e-mail: jmcarrera@ matres-mundi.org 